\title{
The Impact of Government Expenditure on Banten Economic Growth in $2010-2017$
}

\author{
Zaidan Najmuddin ${ }^{1}$ \\ Statistics of Halmahera Tengah - Indonesia
}

\begin{abstract}
Government expenditure is one of the factors driving the economic growth of a region. During 2010 to 2017, realization of Banten government expenditure continued to increase from 11 trillion to 36 trillion. However, Banten's economic growth from 2011 to 2017 tended to slow down from 7.03 percent to 5.71 percent. This study aims to determine how the impact of government expenditure on Banten economic growth and identify government expenditure in the form of capital spending that has a positive effect on Banten economic growth. Capital spending as a component of government expenditure directly related to the government's development program is expected to be able to encourage economic growth in Banten. The method used in this study is the impact analysis of Banten Input-Output (I-O) Table 2010 and panel data regression analysis in eight districts/cities during 2010 to 2017. The results of analysis with IO Table show that government expenditure has a positive impact on Banten's economic growth. Then the panel data regression analysis results show that all types of capital spending have a positive effect, but only spending for road, irrigation, network (BJIJ); and building (BGB) which have proven to have significant effects on Banten's economic growth.
\end{abstract}

Keywords: economic growth, government expenditure, Banten.

${ }^{1}$ Zaidan Najmuddin is a staff at Statistics of Halmahera Tengah. E-mail: zaidan.naj@bps.go.id 


\section{The Impact of Government Expenditure on Banten Economic Growth in $2010-2017$}

Zaidan Najmuddin

\section{Introduction}

\subsection{Background of problems}

The government budget policy at the regional level has been enacted since regional autonomy in 2001 was stipulated through law (undang-undang) number 22 of 1999 as an effort to provide opportunities for regional governments to manage the economy independently. Therefore, local governments have the authority to obtain their own sources of income and the government in accordance with their respective needs based on real and responsible regional economic principles.

Banten as one of the autonomous regions resulting from the division of West Java Province which officially in 2000 until now, in 2017 became a province by sharing the largest Gross Regional Domestic Product (GRDP) of GDP (Gross Domestic Product) by a percentage of 4,10 percent. Figure 1 shows from 2011 to 2017 the economic condition of Banten continues to grow, but its growth tends to slow from 7.03 percent in 2011 to 5.28 percent in 2016, although it edged up to 5.71 percent in 2017.

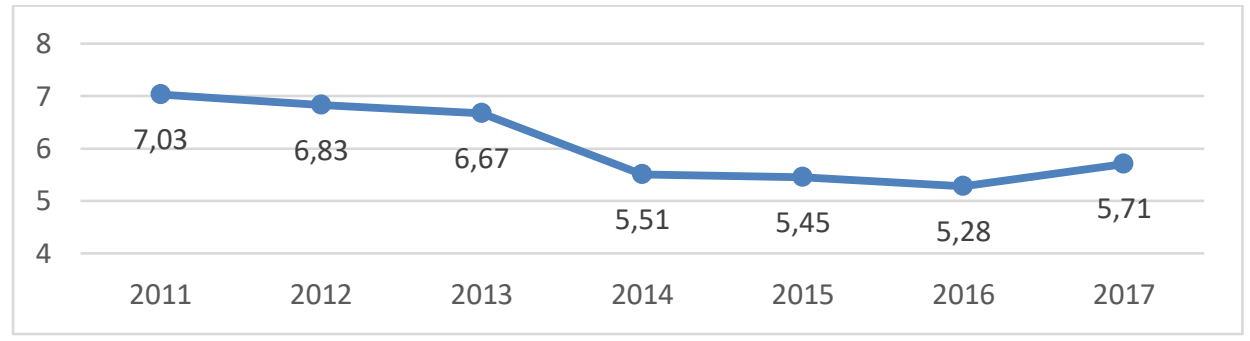

Figure 1. Banten economic growth in 2011-2017 (percent)

Source: Badan Pusat Statistik

On the other hand, from 2010 to 2017 the realization of Banten government expenditure showed a significant increase. Overall, Banten government expenditure increased by 207.42 percent.

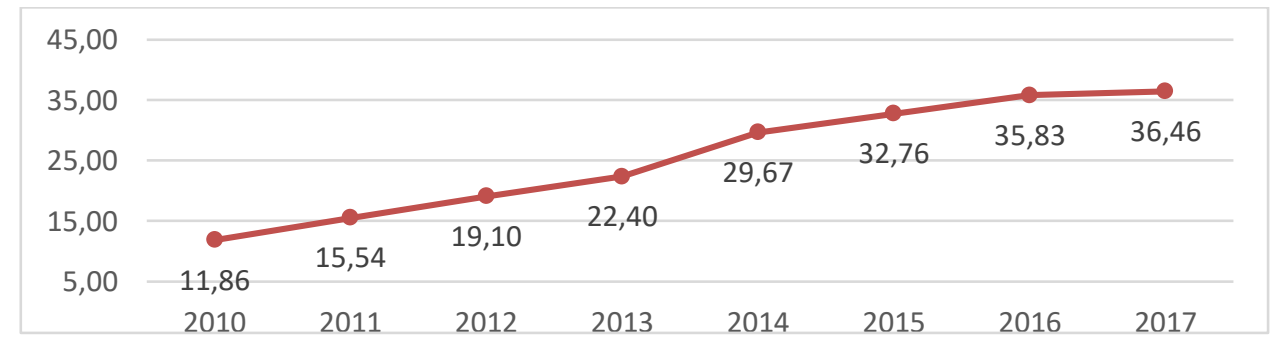

Figure 2. Government expenditure of Banten in 2010-2017 (trillion rupiah)

Source: Direktorat Jenderal Perimbangan Keuangan (processed)

\subsection{The problems}

Government expenditure consists of direct expenditure and indirect expenditure. If seen from the proportion in Table 1, on average 50.86 percent of Banten government expenditure is allocated for direct expenditure, while the remaining 49.14 percent is used for indirect spending. Although the proportion is not far adrift, according to the study of 
Lorena Cakerri et al (2014) government expenditure in the productive sector (in this case capital expenditure) should be able to have a positive impact on economic growth in an area because it is used directly related to government programs, which include capital expenditure component that is directly related to infrastructure development efforts to support economic activity. But the phenomenon that occurs in Banten shows the realization of government spending with a slightly larger proportion of direct expenditure that has not been able to increase the rate of economic growth. Government expenditure continues to increase but economic growth is experiencing a slowdown indicating that the allocation of government spending especially in the direct expenditure component in which there is a component of capital expenditure has not been effective and on target.

Table 1. Proportion of provincial and district/city government expenditure in Banten in the form of indirect and direct expenditure in 2010-2017 (percent)

\begin{tabular}{|c|c|c|}
\hline \multirow{2}{*}{ Series } & \multicolumn{2}{|c|}{ Government Expenditure } \\
\cline { 2 - 3 } & Indirect Expenditure & Direct Expenditure \\
\hline 2010 & 54,33 & 45,67 \\
\hline 2011 & 49,99 & 50,01 \\
\hline 2012 & 48,75 & 51,25 \\
\hline 2013 & 48,58 & 51,42 \\
\hline 2014 & 40,57 & 59,43 \\
\hline 2015 & 49,33 & 50,67 \\
\hline 2016 & 51,82 & 48,18 \\
\hline 2017 & 49,72 & 50,28 \\
\hline Average & 49,14 & 50,86 \\
\hline
\end{tabular}

Related to what has been presented, there are several previous studies relating to the role of government expenditure on economic growth. First Fitriani's studied (2016) showed that there were three types of government spending that had a positive and significant effect on Riau's economic growth, namely spending on road procurement; electricity and telephone; and agricultural tools. Second, research from Muhammad (2017) showed that spending for land; equipment and machinery; building; and roads, irrigation and networks; significant positive effect on economic growth in West Java. The three studies from Putra (2017) showed that government spending in infrastructure has a significant effect on economic growth in West Kalimantan. The four studies from Hermawati (2018) showed that the economic growth of North Kalimantan is affected by land and equipment and machinery expenditure.

Based on the identification of problems that occurred, several objectives were set to be answered in this study, namely providing an overview the economic growth and government expenditure of Banten; analyze the impact of government expenditure on output and value added of the Banten economic sector in 2010, and the impact on Banten economic growth in 2010-2017; simulating the impact of government expenditure on Banten economic growth in 2018 and 2019; and the latter identifies the type of government expenditure in the form of capital expenditure which has a positive and significant effect on the economic growth of Banten.

\subsection{Logical Framework}

In this study, to see further government towards economic growth using the analysis of Input-Output Table. Meanwhile, to allow this type of government publishing in the form of capital expenditure aimed at economic growth Banten uses a regression data panel. 


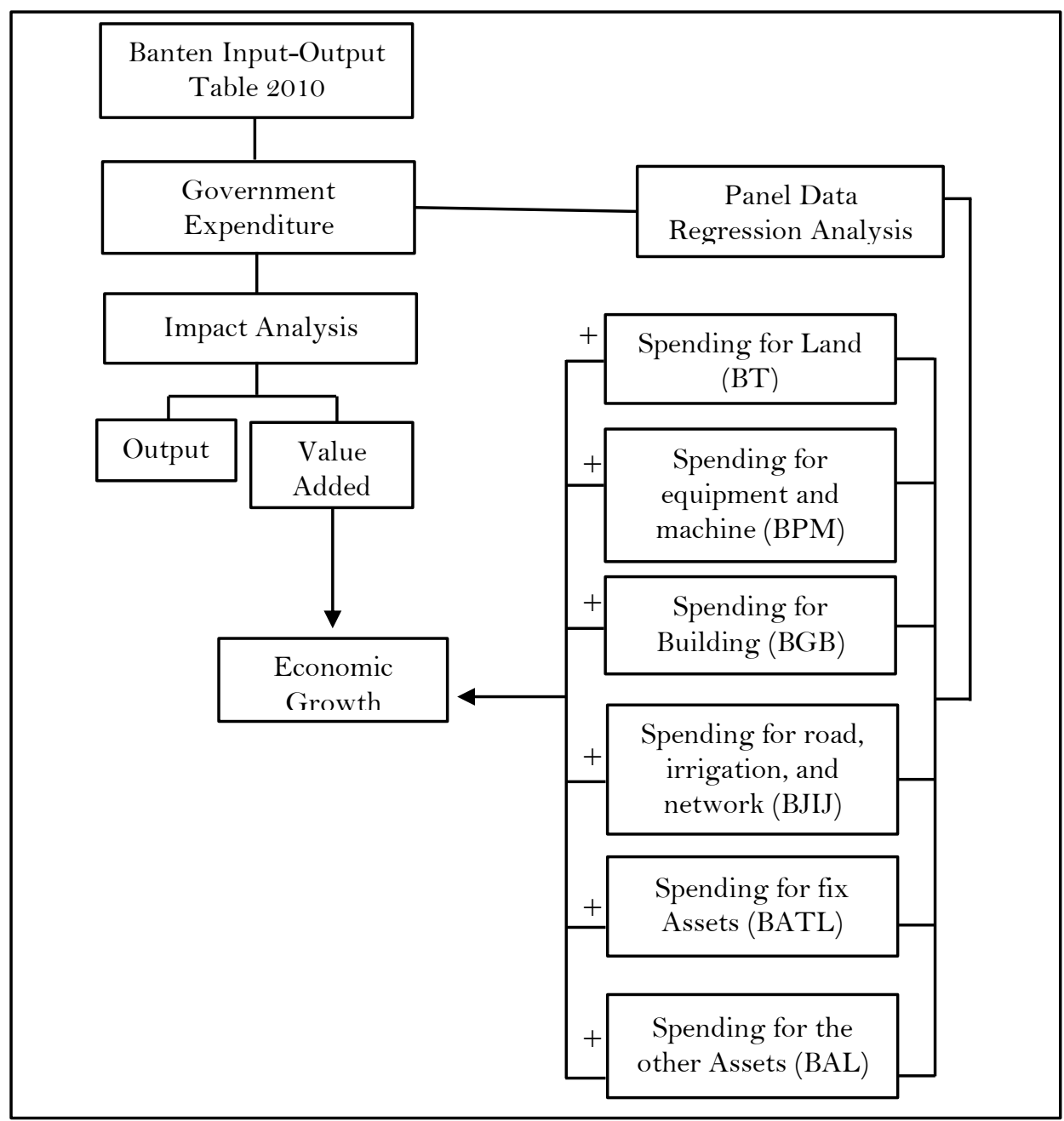

Figure 3. Logical framework of the research

\section{Methods/Methodology}

\subsection{Theoretical Basis}

Keynes in Sadono Sukirno (2000) states that government expenditure is one of the drivers of economic growth in a country and is expected to be able to create a multiplier effect for other economic sectors. One of the points of a study conducted by the National Development Planning Agency (BAPPENAS) in 2006 related to cross-regional and crosssector planning concluded that increasing capital expenditure in fiscal policy would have an impact on improving macroeconomic performance at the central and regional levels.

According to Regulation of the Minister of Finance number 101 of 2011 concerning Budget Classification, capital expenditures are expenditures for payment of assets obtained and $/$ or add value to fixed assets or other assets. These assets must be able to provide benefits for more than one accounting period and their value exceeds the minimum capitalization limit of assets set by the government. In the technical bulletin KSAP (Government Accounting Standards Committee) numbers 02 and 15 of 2014, capital expenditure is used for 6 things, namely land expenditure; equipment and machinery 
shopping; building and building expenditure; road, irrigation and network shopping; expenditure on other fixed assets; and other asset expenditure.

\subsection{Method of Collecting Data}

This study uses secondary data in the form of government expenditure data in 2010-2017 which includes expenditures for land (BT), equipment and machinery expenditure (BPM), building expenditure (BGB), expenditure for road, irrigation and network (BJIJ), other fixed asset expenditure (BATL), and other asset expenditure (BAL) sourced from the Directorate General of Fiscal Balance (DJPK) of the Ministry of Finance. Whereas the economic growth data is obtained from the GDRP value based on constant prices (ADHK) published by the Central Statistics Agency (BPS). In addition, this study also uses the Banten Input-Output Table in 2010 obtained from the BPS publication in Banten Province.

\subsection{Analysis Method}

Descriptive analysis conducted aims to provide an overview of the conditions of economic growth and government expenditure in Banten during the period 2010-2017. The Input-Output Table Analysis is intended to analyze the impact of government spending on output and value added of the Banten economic sector in 2010, the impact on Banten economic growth in 2011-2017, and the simulation of the effects of changes in government spending on Banten economic growth in 2018 and 2019.

Inferencing analysis is aimed to identify the type of government expenditure in the form of capital expenditure that has a positive and significant effect on economic growth in Banten with a panel data regression analysis method consisting of 8 series of time (20102017) and 8 individuals (Pandeglang Regency, Serang Regency, Cilegon City, Tangerang City, Serang City, South Tangerang City, Lebak Regency and Tangerang Regency). Here are three models that will be tested to get the best model as a tool for estimating panel data:

a. Common Effect Model (CEM)

$$
\begin{aligned}
\ln Y_{i t}= & \alpha+\beta_{1} \ln X_{1 i t}+\beta_{2} \ln X_{2 i t}+\beta_{3} \ln X_{3 i t}+\beta_{4} \ln X_{4 i t}+\beta_{5} \ln X_{5 i t} \\
& +\beta_{6} \ln X_{6 i t}+u_{i t}
\end{aligned}
$$

b. Fixed Effect Model (FEM)

$$
\begin{gathered}
\ln Y_{i t}=\left(\alpha+\mu_{i}\right)+\beta_{1} \ln X_{1 i t}+\beta_{2} \ln X_{2 i t}+\beta_{3} \ln X_{3 i t}+\beta_{4} \ln X_{4 i t}+\beta_{5} \ln X_{5 i t} \\
+\beta_{6} \ln X_{6 i t}+v_{i t}
\end{gathered}
$$

c. Random Effect Model (REM).

$$
\begin{aligned}
\ln Y_{i t}=\alpha & +\beta_{1} \ln X_{1 i t}+\beta_{2} \ln X_{2 i t}+\beta_{3} \ln X_{3 i t}+\beta_{4} \ln X_{4 i t}+\beta_{5} \ln X_{5 i t} \\
& +\beta_{6} \ln X_{6 i t}+\left(\mu_{i}+v_{i t}\right)
\end{aligned}
$$

Explanation:

$\begin{array}{ll}\mathrm{Y}_{i t} & : \text { dependent variable from the } \mathrm{i} \text {-th individual in the t-period } \\ \alpha & : \text { intercept } \\ \beta_{1}, \ldots, \beta_{6} & : \text { regression parameter for } 1 \text { st, } 2 \text { nd, 3rd, 4th, } 5 \text { th, } 6^{\text {th }} \text { varible } \\ X_{1 i t}, \ldots, X_{6 i t} & : \text { independent variable } 1^{\text {st }} \text { to } 6 \text { th from i-th individual in t-period } \\ \mathrm{i} & : \text { individual }(1,2, \ldots, \mathrm{N}), \mathrm{N}=8 \\ \mathrm{t} & : \text { time series }(1,2, \ldots, \mathrm{T}), \mathrm{T}=8 \\ u_{i t} & : \text { total error } \\ \mu_{i} & : \text { individual effect } \\ v_{i t} & : \text { error from i-th individual in t-period }\end{array}$


III. Results, Analysis, and Discussions

3.1. Banten Economic Growth Conditions

Table 2. Value of GDRP (trillion rupiah) and economic growth (percentage) of Banten in 2010-2017

\begin{tabular}{|c|c|c|c|c|c|c|c|c|}
\hline Year & 2010 & 2011 & 2012 & 2013 & 2014 & 2015 & 2016 & 2017 \\
\hline $\begin{array}{c}\text { GDRP by } \\
\text { constant price }\end{array}$ & 271,46 & 290,54 & 310,38 & 331,09 & 349,35 & 368,37 & 387,83 & 410,04 \\
\hline $\begin{array}{c}\text { Economic } \\
\text { Growth }\end{array}$ & - & 7,03 & 6,83 & 6,67 & 5,51 & 5,45 & 5,28 & 5,71 \\
\hline
\end{tabular}

Source: BPS (processed)

GDRP value based on constant prices (ADHK) achieved by Banten in 2010 reached 271.46 trillion rupiah, increasing to 290.54 trillion rupiah (2011), 310.38 trillion rupiah (2012), 331.09 trillion rupiah (2013), 349.35 trillion rupiahs (2014), 368.37 trillion rupiahs (2015), 387.83 trillion rupiahs (2016) and continues to increase to 410.04 trillion rupiahs in 2017. However, the rate of economic growth from year to year tends to slow down. The highest economic growth was achieved in 2011 with 7.03 percent and the lowest occurred in 2016 with 5.28 percent.

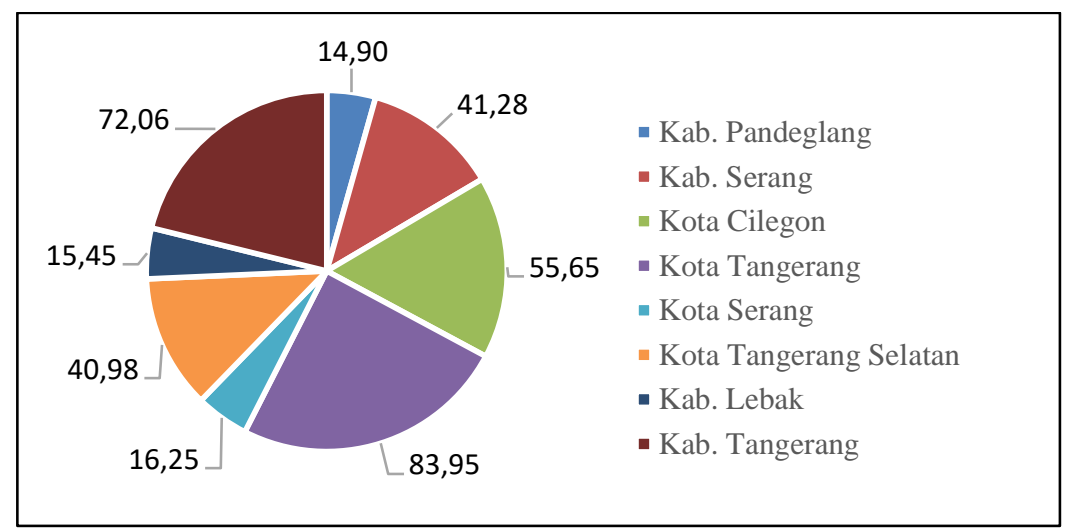

Figure 4. Average GDRP according to Regency/City in Banten in 2010-2017 (trillion rupiah)

Source: BPS (processed)

\subsection{Realization of Banten Government Expenditures}

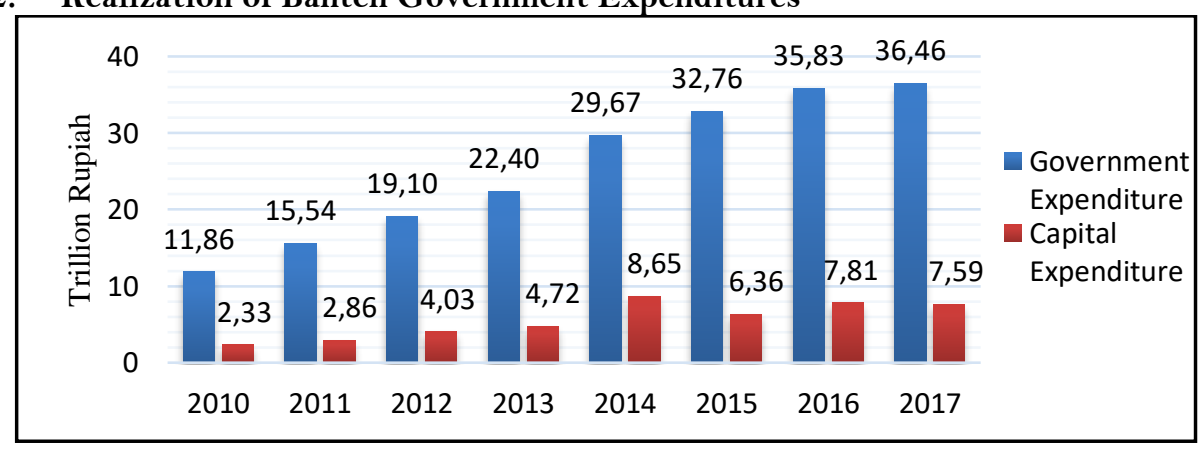

Figure 5. Government expenditure and capital spending in Banten 2010-2017

Source: DJPK (processed)

Over the past eight years, the realization of Banten government expenditure has tripled from 11.46 trillion rupiah in 2010 to 36.76 trillion rupiah in 2017. Each year the 
realization of Banten government expenditure and all regencies / cities in this region always experiences an average increase of 18 percent. The use of regional spending that continues to increase should be able to build the economy in Banten.

Same with the total government expenditure, government spending in the form of capital expenditure also increased three-fold greater than 2.33 trillion rupiah in 2010 to 7.59 trillion rupiah in 2017. This situation lasted until 2014 which is the highest capital expenditure realization in the last eight years, which is 8.65 trillion rupiah. While the realization of capital expenditure in 2015, 2016 and 2017 tends to fluctuate.

\subsection{I-O Table Analysis}

\subsubsection{Impact of government expenditure on output of the economic sector in} Banten

The following is a summary table of the five sectors that have the greatest output impact due to the magnitude of Banten government expenditure in 2010:

Table 3. Five sectors with the biggest impact on output resulting from the total of Banten government expenditure in 2010 (trillion rupiah), processed

\begin{tabular}{|c|l|c|}
\hline Number & Economic Sector & Impact on Output \\
\hline 1 & Government administration & 3,816 \\
\hline 2 & Construction & 2,779 \\
\hline 3 & Wholesale and retail trade & 1,934 \\
\hline 4 & Health services and social activities & 1,451 \\
\hline 5 & Educational services & 0,907 \\
\hline & Other Sectors & 5,529 \\
\hline & Total & 16,418 \\
\hline
\end{tabular}

If seen in total, the Banten government expenditure in 2010 had an impact on the formation of the largest output in the government administration sector and the construction sector, each totaling 3.816 trillion rupiahs and 2.779 trillion rupiahs. In total, the percentage of output formed as a result of Banten government expenditure in 2010 was 2.95 percent.

\subsubsection{Impact of government expenditure on gross value added (NTB) of the economic sector in Banten}

The following is a summary table of the five sectors that have the greatest value added impact due to the magnitude of Banten government expenditure in 2010:

Table 4. Five sectors with the biggest impact on NTB as a result of Banten total government expenditure in 2010 (trillion rupiah), processed

\begin{tabular}{|c|l|c|}
\hline Number & \multicolumn{1}{|c|}{ Sectors } & Impact on Value Added \\
\hline 1 & Government administration & 3,816 \\
\hline 2 & Construction & 0,918 \\
\hline 3 & Wholesale and retail trade & 0,804 \\
\hline 4 & Health services and social activities & 0,572 \\
\hline 5 & Educational services & 0,537 \\
\hline \multicolumn{2}{|c|}{ Other sectors } & 2,456 \\
\hline & Total & 9,105 \\
\hline
\end{tabular}

If seen as a whole, Banten government expenditure in 2010 had the greatest impact on the formation of NTB in the government administration and construction sector, each with 3.816 trillion rupiahs and 0.918 trillion rupiahs. In total, the percentage of NTB formed as a result of Banten government expenditure in 2010 was 3.94 percent. 


\subsubsection{The impact of government expenditure changes on Banten economic growth in 2011-2017}

Table 5. The impact of government expenditure changes on Banten economic growth in 2011-2017, processed

\begin{tabular}{|l|c|c|c|c|c|c|c|}
\hline Year & 2011 & 2012 & 2013 & 2014 & 2015 & 2016 & 2017 \\
\hline $\begin{array}{l}\text { Government } \\
\text { Expenditure Changes }\end{array}$ & 30,97 & 22,95 & 17,27 & 32,46 & 10,40 & 9,37 & 1,76 \\
\hline $\begin{array}{l}\text { The impact on } \\
\text { Economic Growth }\end{array}$ & 1,06 & 0,90 & 0,81 & 1,47 & 0,87 & 0,61 & 0,16 \\
\hline
\end{tabular}

Based on table 5, during 2011 to 2017 the government expenditure in Banten always increased. The increase that occurred fluctuated so that the impact on Banten's economic growth also fluctuated. The largest increase in government expenditure occurred in 2014 which amounted to 32.46 percent, the impact on the economic growth of Banten was 1.47 percent. While the lowest increase in government expenditure occurred in 2017 which was 1.76 percent, the low increase in government expenditure this year had the lowest impact on Banten's economic growth during 2010-2017 which was only 0.16 percent.

\subsubsection{Simulation of the impact of changes in government expenditure on economic growth in Banten in 2018 and 2019}

Changes in government expenditure contained in Banten RAPBD have a positive impact on economic growth in Banten. In 2018 Banten government expenditure is budgeted 0.09 percent greater than the previous year, the impact given to economic growth is predicted to be quite low at only 0.03 percent. Meanwhile, in 2019 the Banten government expenditure is budgeted to increase by 6.08 percent and is predicted to have a greater impact on Banten's economic growth of 0.46 percent. This shows that the increase in government expenditure budget is directly proportional to its impact on Banten economic growth, the greater budgeted increase in government expenditure, the impact on economic growth also increases.

Table 6. Simulation of the impact of changes in government expenditure on economic growth in Banten in 2018 and 2019

\begin{tabular}{|c|c|c|}
\hline Year & $\begin{array}{c}\text { The plan of Government } \\
\text { expenditure budget changes. }\end{array}$ & $\begin{array}{c}\text { Prediction of impact on economic } \\
\text { growth }\end{array}$ \\
\hline 2018 & 0,09 & 0,03 \\
\hline 2019 & 6,08 & 0,46 \\
\hline
\end{tabular}

Source: Banten RAPBD for the plan of Government expenditure budget changes.

\subsection{Panel Data Regression Analysis}

In the panel data regression there are three models to be chosen, namely the common effect model (CEM), fixed effect model (FEM), and random effect model (REM). To get an estimator that is close to the actual situation based on available data, the best model of the three models is tested.

Tabel 7. Model Meaning Criteria

\begin{tabular}{|c|c|c|c|}
\hline Variable & coefficient & Std, Error & t-statistic \\
\hline
\end{tabular}




\begin{tabular}{|c|c|c|c|}
\hline $\mathrm{C}$ & 9,394878 & 0,108528 & 86,56650 \\
\hline $\operatorname{lnBT}$ & 0,010074 & 0,007164 & 1,406210 \\
\hline $\operatorname{lnBPM}$ & 0,021591 & 0,023214 & 0,930059 \\
\hline $\operatorname{lnBGB}$ & 0,053814 & 0,019054 & 2,824314 \\
\hline $\operatorname{lnBJIJ}$ & 0,134550 & 0,016172 & 8,319777 \\
\hline lnBATL & 0,005448 & 0,010483 & 0,519729 \\
\hline $\operatorname{lnBAL}$ & 0,000437 & 0,008380 & 0,052147 \\
\hline \multicolumn{4}{|c|}{ Statistics Summary } \\
\hline $\mathrm{R}^{2}$ & 0,992275 & F-statistic & 494,0539 \\
\hline Adjusted $\mathrm{R}^{2}$ & 0,990267 & $P$-value (F-stat) & 0,000000 \\
\hline
\end{tabular}

Based on the results of the model selection test, the variance-covariance residual matrix structure test and the classical assumption test, the best model used in this study is FEM with the SUR (Seemingly Unrelated Regression) estimation method. Then the model formed is as follows:

$$
\begin{aligned}
\ln (P \widehat{D R B})_{l t}= & \left(9.394878+\mu_{i}\right)+0.010074 \ln (B T)_{i t}+0.021591 \ln (B P M)_{i t}+ \\
& 0.053814^{*} \ln (B G B)_{i t}+0.134550^{*} \ln (B J I J)_{i t}+0.005448 \ln (B A T L)_{i t}+ \\
& 0.000437 \ln (B A L)_{i t}
\end{aligned}
$$

Explanation $: *$ significant in $\alpha=5 \%$

Based on the test results in Table 7 , the $\mathrm{F}$ test shows significant results, so there is enough evidence to say that in the model there is at least one variable of capital expenditure changes that significantly affects the economic growth of Banten. Then the adjusted $\mathrm{R}^{2}$ value of 0.9902 indicates that 99.02 percent of the diversity of Banten economic growth can be explained by the capital expenditure variables in the model.

Partially, there are two capital expenditure variables that are proven to have a positive and significant influence. The first variable is road, irrigation and network expenditure (BJIJ) which has a coefficient of 0.134 with the interpretation that if BJIJ increases by one percent, then economic growth will increase by 0.134 percent, assuming other variables are constant (ceteris paribus). The second variable is building expenditure (BGB) which has a coefficient of 0.054 with an interpretation that if BGB increases by one percent, then economic growth will increase by 0.054 percent assuming other variables are constant. These results are consistent with Muhamad's research (2017) which states that the variable spending on roads, irrigation, and networks, as well as building expenditure has a significant and positive effect on economic growth in West Java and also in accordance with Fitriani's (2016) research which shows that the variable roads have a significant effect on Riau's economic growth.

BJIJ is the type of expenditure that has the most significant influence on Banten economic growth based on the model formed. The realization of this type of expenditure is in the form of procurement of roads, bridges, clean water lines, and electricity networks which are the basic infrastructure to drive the wheels of the economy. As for BGB, although the effect is not as large as road, irrigation, and networks spending, the construction of buildings that are utilized optimally in addition to being a fixed asset of the regional government, buildings that have been erected can create jobs so as to trigger economic activity in the region. This condition is in line with Putra's research (2017) which states that government spending in infrastructure has a significant effect on economic growth.

Meanwhile, the four capital expenditure variables that have a positive influence but the effect is not big enough, namely land expenditure (BT), equipment and machinery expenditure (BPM), other fixed asset expenditure (BATL), and other asset expenditure (BAL). Although the variables used are the same as those of Muhamad (2017) and 
Hermawati (2018), the results are not in line between one study and another, there can be explained by the characteristics of different research areas because each region has different development needs and priorities, so that budget policies in a certain area cannot be immediately applied in another area.

In the model used, there are individual effects that differ between districts/cities in Banten but the magnitude is fixed from time to time. Kota Tangerang, has the highest positive individual effect, while Lebak Regency has the lowest negative individual effect. This means that at the same level of expenditure on capital expenditure, the average of Kota Tangerang is always higher than other districts/cities in Banten, and vice versa with Kabupaten Lebak.

\section{Conclusion and Recommendation}

1. Banten's economic growth slowed during 2011-2017. Meanwhile, districts/cities that have the largest amount of GDRP are Kota Tangerang and the lowest are Kabupaten Pandeglang. In terms of government expenditure, the average of Banten government expenditure is used for capital expenditure, which is dominated by road, irrigation and network spending.

2. Banten government expenditure has a positive impact on output and NTB of Banten economic sector in 2010 and also for the economic growth of Banten in 2011-2017. The greatest impact of government expenditure on output and NTB was felt by the government administration sector and the construction sector, while the impact on economic growth was greatest in 2014.'

3. Simulations using provincial and district/city RAPBDs in Banten in 2018 and 2019 show that the increase in government expenditure budget is directly proportional to the impact on Banten economic growth, the greater budgeted increase in government expenditure, the greater impact on economic growth.

4. All types of capital expenditure have a positive effect, but only two types of capital expenditure have a significant effect on the economic growth of Banten, namely BJIJ and BGB. At the same level of capital expenditure, the average economic growth of Kota Tangerang is always higher than other regencies / cities in Banten.

In an effort to provide broad benefits, the following are some suggestions that can be given from research that has been done:

1. For the provincial and district/city governments in Banten, it is expected to pay more attention to economic sectors that contribute greatly to the economy and allocate greater capital expenditure for types of capital expenditure that have a significant influence on economic growth, namely the BJIJ and BGB.

2. For further research, it is expected to use more specific variables, for example by splitting road, irrigation and network spending into road by itself, irrigation by itself, and others, and also adding to the longer research time series.

\section{References}

Badan Perencanaan Pembangunan Nasional. (2006). Penyusunan Model Perencanaan Lintas Wilayah dan Lintas Sektor. Jakarta: BAPPENAS.

Cakerri, L., Migena, P., Oltiana, M. (2014). The effect of government expenditures on economic growth. The case of Albania. European Journal of Social Sciences Education and Research, 1(2), 2312-8429.

Cahyono, Budi. \& Bagus, Sumargo. (2005). Mengartikulasikan Tabel Input-Output dan Kerangka Analisisnya. Journal the WINNERS, 6 (1).

Fitriani. (2016). Analisis Sektor Unggulan dan Pengaruh Pengeluaran Pemerintah Terhadap Pertumbuhan Ekonomi Riau Tahun 2006-2014. Sekolah Tinggi Ilmu Statistik, Jakarta. 
Hermawati, Wulandari (2018). Pengaruh Belanja Modal Terhadap Pertumbuhan Ekonomi Kabupaten/Kota di Provinsi Kalimantan Utara. Program Pascasarjana Universitas Terbuka, Jakarta.

Komite Standar Akuntansi Pemerintahan. (2014). Buletin Teknis No 15 Tentang Akuntansi Aset Tetap Berbasis Akrual. Jakarta: KSAP.

Komite Standar Akuntansi Pemerintahan. (2014). Buletin Teknis No O2 Tentang Penyusunan Neraca Awal Pemerintah Daerah. Jakarta: KSAP.

Muhammad, Fatoni Alauddin. (2017). Analisis Pengaruh Belanja Modal Pemerintah Terhadap Pertumbuhan Ekonomi Kabupaten Kota di Provinsi Jawa Barat Tahun 2010-2015. Sekolah Tinggi Ilmu Statistik, Jakarta.

Putra, Windhu. (2017). Dampak Pengeluaran Pemerintah Terhadap Pertumbuhan Ekonomi dan Indeks Pembangunan Manusia di Perbatasan Indonesia. Jurnal Ekonomi, Bisnis dan Kewirausahaan, 6 (2), 120-138.

Sukirno, Sadono. (2000). Teori Pengantar Makroekonomi. Jakarta: Raja Grafindo Persada. 